\title{
Investigation of the Perceptions of Students on Mathematics Course via the Pictures They Draw
}

\author{
Cemil Inan \\ Faculty of Education, Dicle University, Turkey
}

Copyright (C) 2015 by authors, all rights reserved. Authors agree that this article remains permanently open access under the terms of the Creative Commons Attribution License 4.0 International License

\begin{abstract}
The study aimed to scrutinize the perceptions of middle school students on the course of mathematics by using the pictures they drew. In the study conducted with 211 students attending two middle schools in Diyarbakir district center and in a village in 2014-2015 academic year, qualitative research design and phenomenology model were utilized. Content analysis was conducted in the study and at the end of the study, the following categories in the perceptions of the students on the course of mathematics were found: "numbers-infinity, functionality, improvement of mental capacity, requirement for acquiring a profession, basic science containing logic, hard and confusing, created by figures and patterns, requiring effort to learn." The pictures drawn by students were mostly in "functionality in life" category and in "requiring an effort to learn" category the least, respectively. As a result, the common theme that there was a positive perception for mathematics and the attention and the experience of teachers were the basic reasons for that perception was reflected in most drawings.
\end{abstract}

Keywords Perception Related to the Course of Mathematics, Drawing, Picture, Perception on the Course of Mathematics, Student Drawings

\section{Introduction}

Painting brings us experienced the world faces to face. Every artist and draws his own different known objects. These objects, lemon, guitars, bulls, does not go in front of our eyes; it takes place in our memory. There are no insignificant details in the art object, the surface of the material, texture, shape, color is significant, Art objects in a simulated world is a world in itself: the movement, shape, and color is a self-contained world. The deep meaning of a work of art, the size, shape, proportion, color and movement are all created.

Four trends in art form direct;

- Realistic eye reflection of representatives object image
- Forms of gratification in the quest for balanced regulation that -composition- fiction; the visual system is the ability to edit format

- Moving objects images- continuous scanning of the eye, choose the format that will satisfy the structure that extracts images of stationary objects not detected

- Mood, tension, and internal contradictions, selective element for the artist determines the meaning and form. Highlighted the human body during certain periods, consumption in other periods, nature is emphasized in another era.

The detection capability of the human form in art and fiction, it even has a close relationship between the body's behaviors.

Mathematics is a tool used to improve the skills of critical questioning power, ability to examine and research and to study with attention and order (Ünlü, 2007). Mathematics is a common tool of elaboration among humans. It helps humans to acquire self-knowledge and to know the universe. It creates a basis for all activities (Yenilmez, 2007).

Mathematics is a powerful and universal communications tool. It was a common language for humanity all throughout the history. An adult individual needs mathematics to continue daily life and for a higher education. Mathematics is a tool to reach universal truth and of logical thinking (Y1lmaz, 2006).

Mathematics is one of the leading courses that the students shun and are afraid of. The reason for this fear is not the difficulty of the mathematics courses, but the effects of the positive or the negative attitude that the students develop especially during the primary school years (Taşdemir, 2009). Positive attitude denotes positive emotional disposition for mathematics course, whereas negative attitude denotes negative disposition. Emotional disposition contains beliefs and emotions (Zan and Martiono, 2007).

Several studies were conducted to scrutinize the perceptions of students on the course of mathematics. It was observed that the studies in the field often utilized scales to determine the perceptions on mathematic courses. Student drawings are one of the tools that could be used to determine 
emotions and thoughts of students.

Drawings help develop creativity, self-expression and to define one's emotions and thoughts (Kesicioğlu and Deniz, 2012). Drawing a picture is a process that combines different experiences to create something personal, unique and brand new (Ersoy and Türkkan, 2009). Student drawings that are used in education and psychology have attracted the interest of psychologists and education professionals since the 1930's. Student drawings are considered as the aesthetical manifestation of their emotions (Johnson and Gloye, 1958).

Colors and subjective symbols that students use in drawings and the level of the drawing skills of the student could make it difficult for the researcher to evaluate the drawing of the student. When drawings are supported with written expressions, objective evaluation is consolidated.

Using written expressions, children become efficient in expressing the subject matter they speak or write using existing knowledge and experiences they have. They learn new information, gain new experiences, discover the reasons for events, estimate their outcomes, and narrate their knowledge and experiences based on their own lives. Written expression demonstrates skills of thinking and imagining of the students of the observation power within the common sense and the skill to use his or her mother language (Belet and Türkkan, 2007).

The general aim of this study is to investigate the perceptions of middle school students on mathematics course through their drawings and written explanations.

\section{Methodology}

This study aimed to determine the perceptions of middle school students on mathematics course via drawings they have drawn. Thus, the current situation was described utilizing a qualitative approach without presenting any statistical data. This study was conducted using phenomenology design, one of the qualitative research designs.

Phenomenology studies usually focus on discovery or interpretation of perceptions or perspectives about a certain case. Phenomenology aims to discover or interpret personal perceptions or points of view on a particular case. Researcher aims to determine a set of different meanings in addition to the determination of logical structure relationship of different meanings in phenomenology (Akerlind, 2012; Yıldırım and Şimşek, 2005).

\section{Study Group}

211 students attending 2 middle schools in central and peripheral Diyarbakır province in 2014-2015 academic year participated in the study.

\section{Data Collection Tool}

All participants of the study were asked to draw a picture that reflects their thoughts on mathematics course and explain their picture in writing. Students drew their paintings on paper sheets provided by the researchers without any interference.

\section{Analysis of Data}

Initially, the drawings made by children were examined and those that did not reflect an idea were excluded from the study. Remaining drawings were reevaluated and divided into certain categories based on the expressions of drawings themselves and the written explanations on the drawings. Finally, the frequencies and percentages of drawings that were thought to represent these categories were calculated.

\section{Findings}

This section analyzed the drawings of students about the mathematics course based on their similarities under certain conceptual categories and numerical information on these categories is presented.

Table 1 demonstrates the conceptual categories formed by the drawings that reflect the thoughts of the students on mathematics course, and the frequencies (f) and the percentages (\%) of the occurrences of these categories. In the second part of the section, examples of the drawings that represent the categories are presented.

Table 1. Categories formed by the drawings by students on mathematics course

\begin{tabular}{ccc}
\hline Category of Drawing & $\begin{array}{c}\text { Indication } \\
\text { frequency (f) }\end{array}$ & $\begin{array}{c}\text { Percentage } \\
\mathbf{( \% )}\end{array}$ \\
\hline Functional in life & 46 & 21.8 \\
Formed by infinity and & 39 & 18.5 \\
numbers & 27 & 12.8 \\
Develops mental activity & 26 & 12.3 \\
Required for job acquisition & 22 & 10.4 \\
Funny and game-like & 16 & 7.6 \\
A basic science containing & 16 & 7.6 \\
logic & 12 & 5.7 \\
Difficult and confusing & 7 & 3.3 \\
Formed by figures and patterns & $\mathbf{2 1 1}$ & $\mathbf{1 0 0}$ \\
\hline Learned with effort & & \\
\hline Total &
\end{tabular}

It was observed that the most frequent drawings were in the category of "functionality" $(46,21.8 \%)$ and the least frequent drawings were in the "learned with effort" category $(7,3.3 \%)$. 


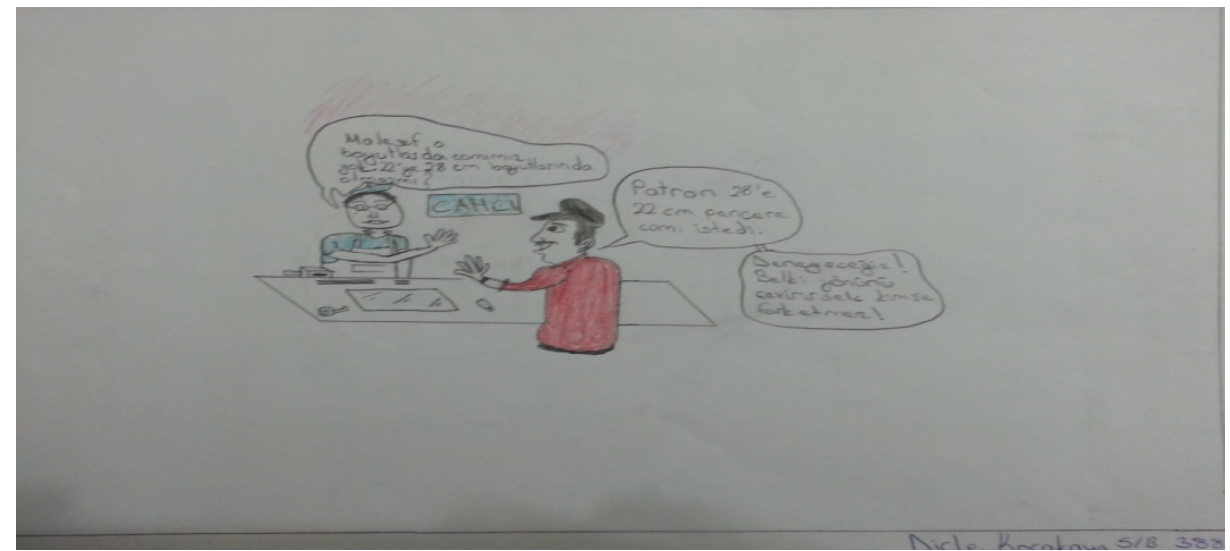

Drawing 1

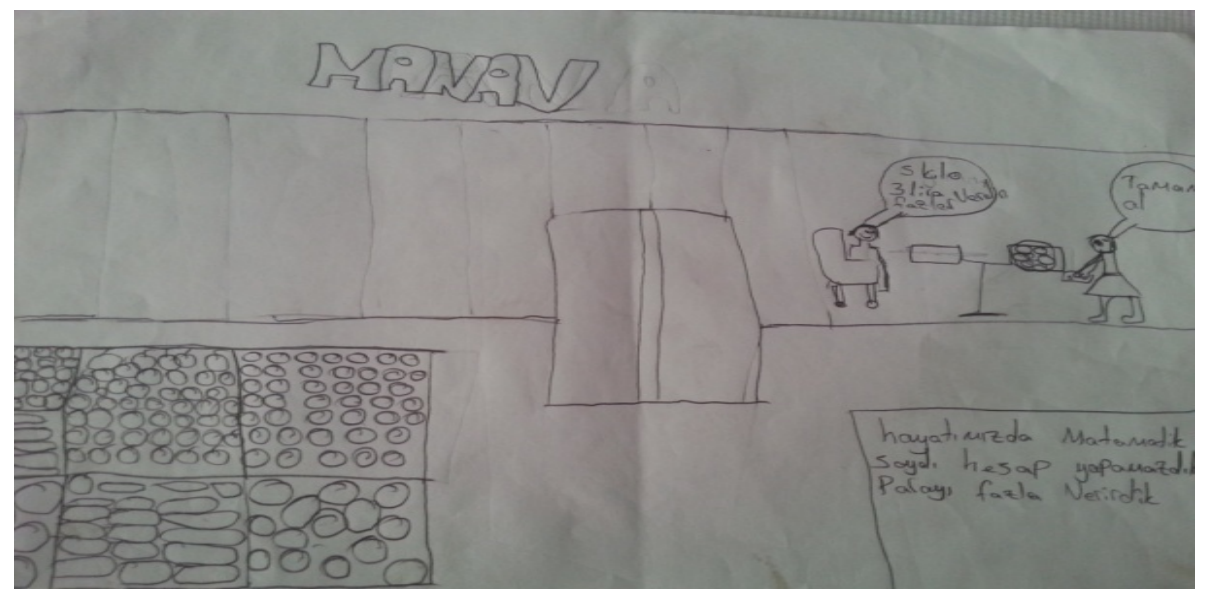

Drawing 2

When the drawings in the category of "infinity and numbers" were examined, it was observed that students have written nested numbers on a spiral plane, filling the paper sheet with numbers. Some of the drawings representing "infinity and numbers" category are displayed below:

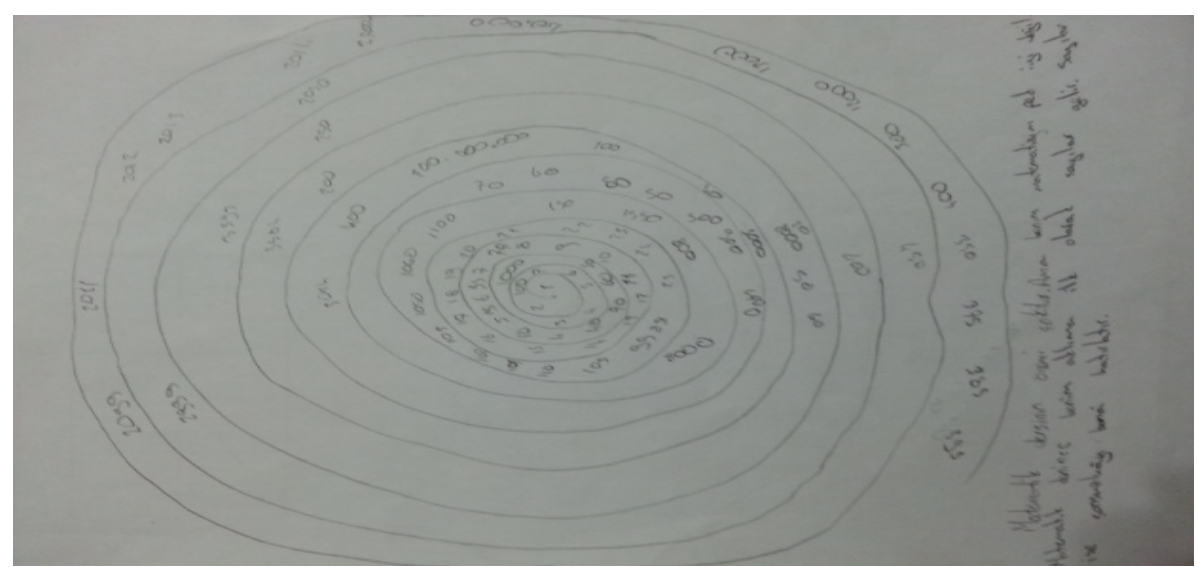

Drawing 3 


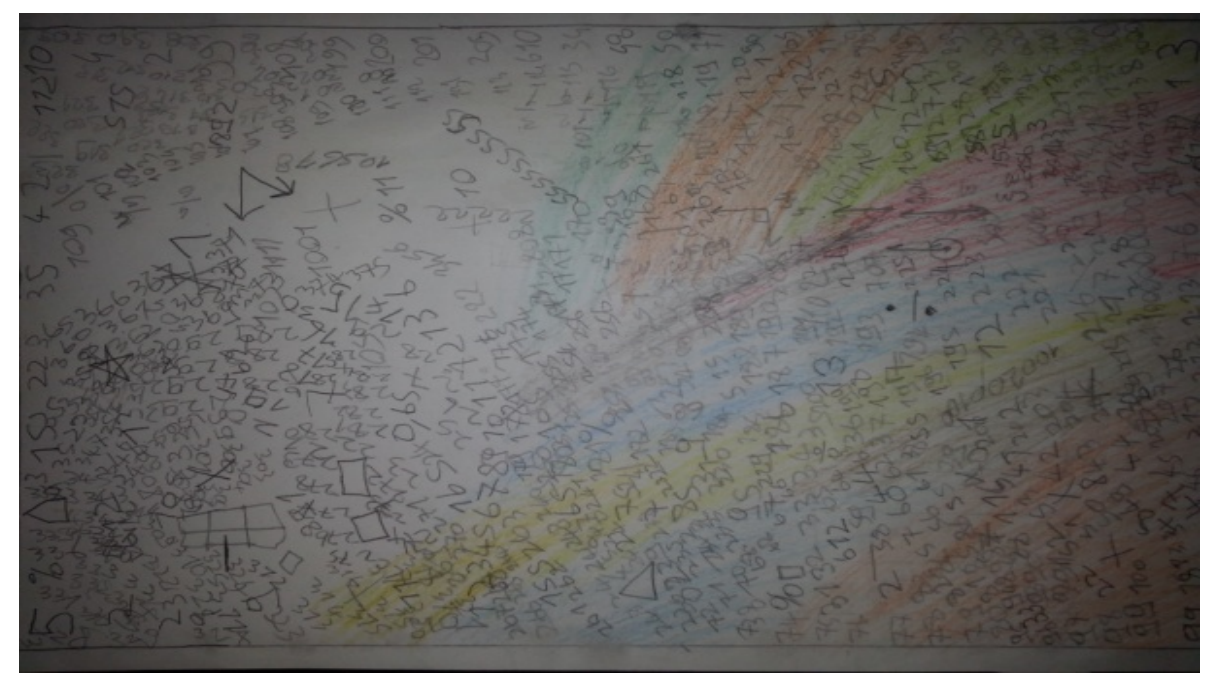

Drawing 4

When the drawings and the explanations written on the drawings by the students in the category of "developing mental activity" were examined, it was observed that they thought mathematics was the best course that developed mental activity. Some of the drawings representing this category are displayed below:

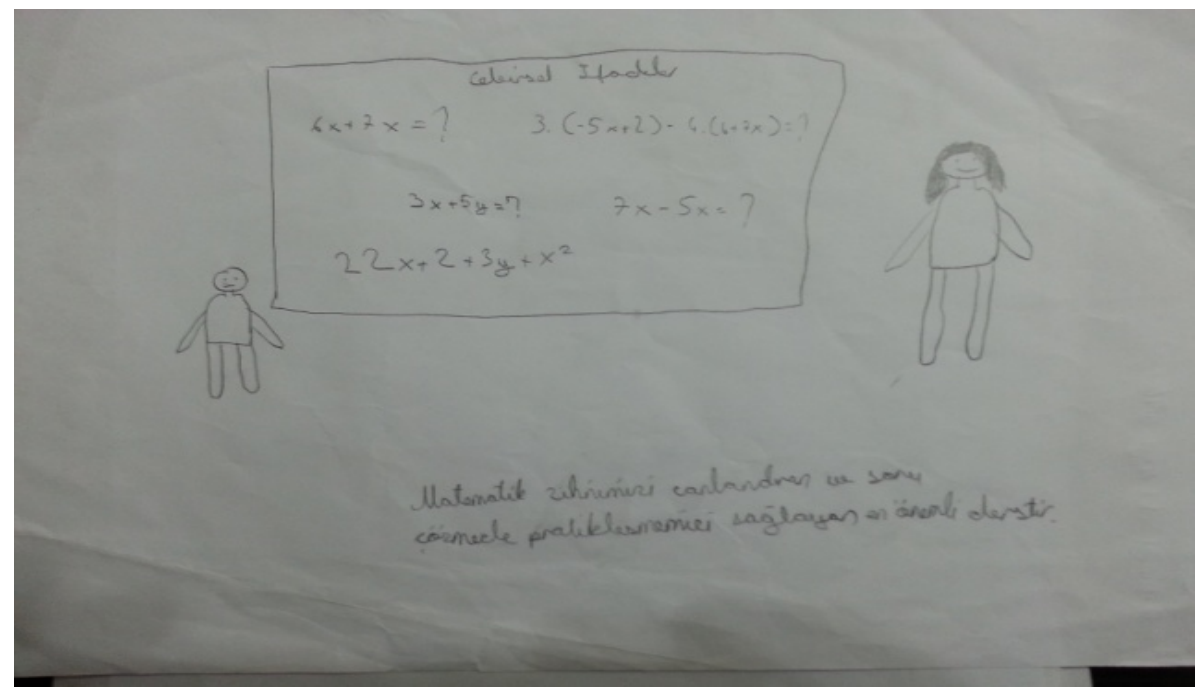

Drawing 5

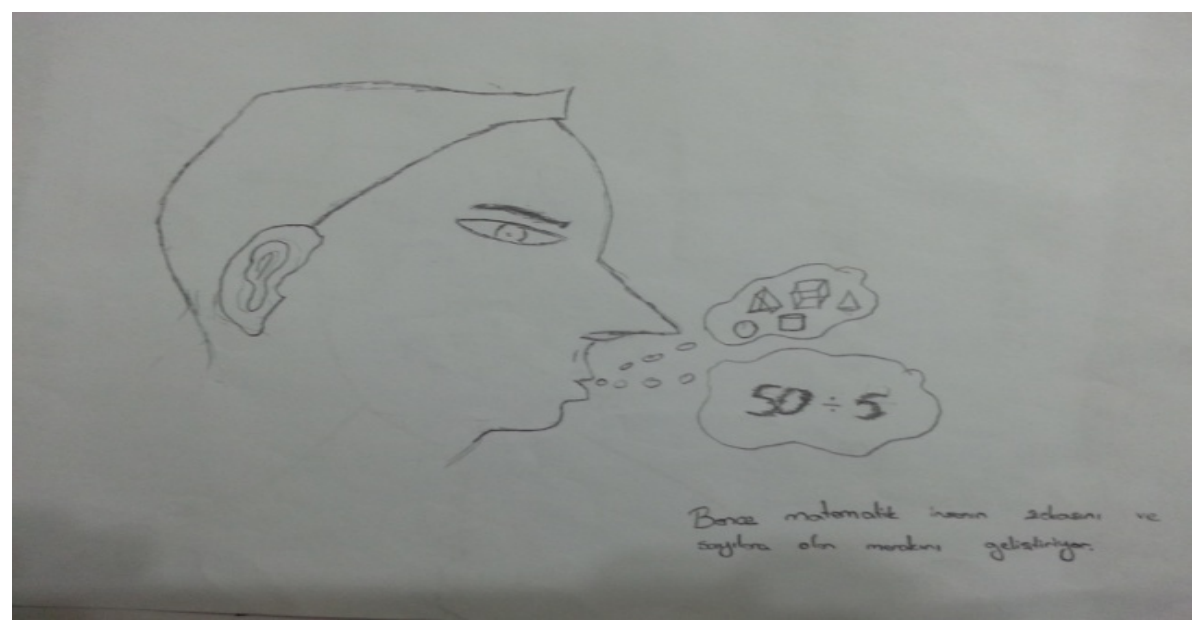

Drawing 6 
When the drawings and the explanations written on the drawings by the students in the category of "required for job acquisition" were examined, it was observed that the students viewed the mathematics course to bring success when a student gets good grades and brings success in the university exams causing the students to reach their desired occupations. Some of the drawings representing this category are displayed below:

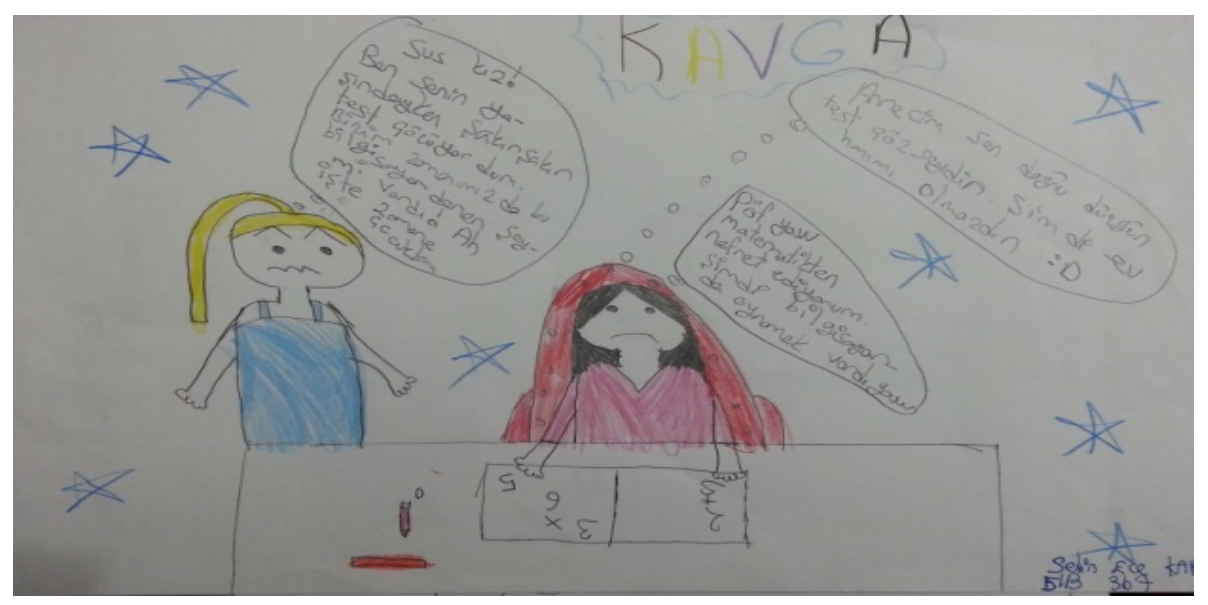

Drawing 7

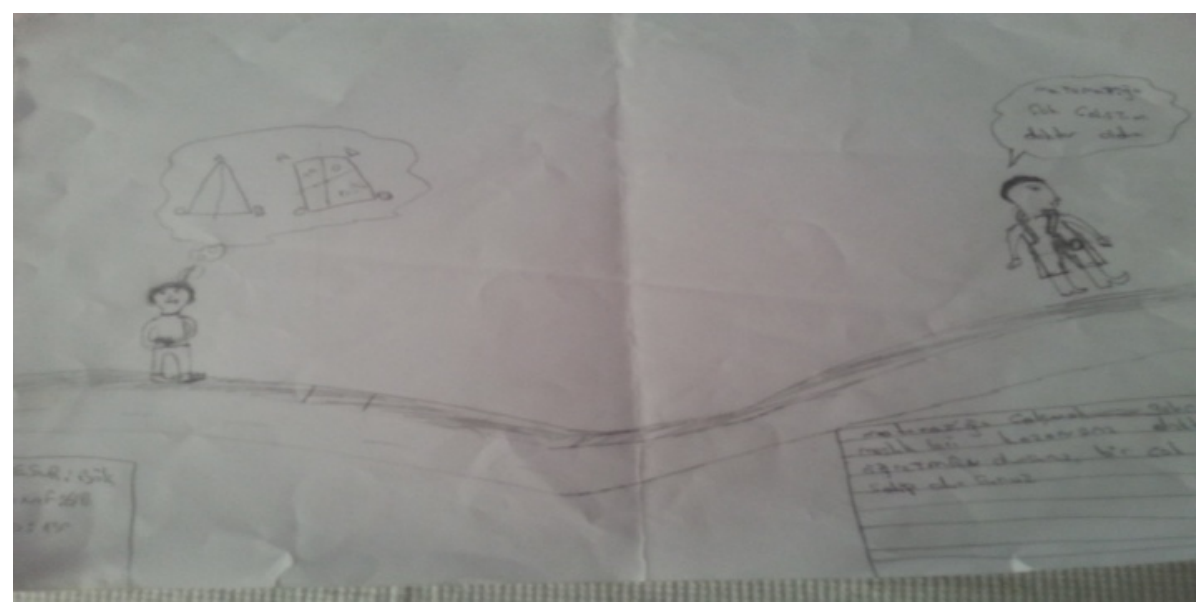

Drawing 8

When the drawings and the explanations written on the drawings by the students in the category of "funny and game-like" were examined, it was observed that students drew about mathematics competitions. Some of the drawings representing this category are displayed below:

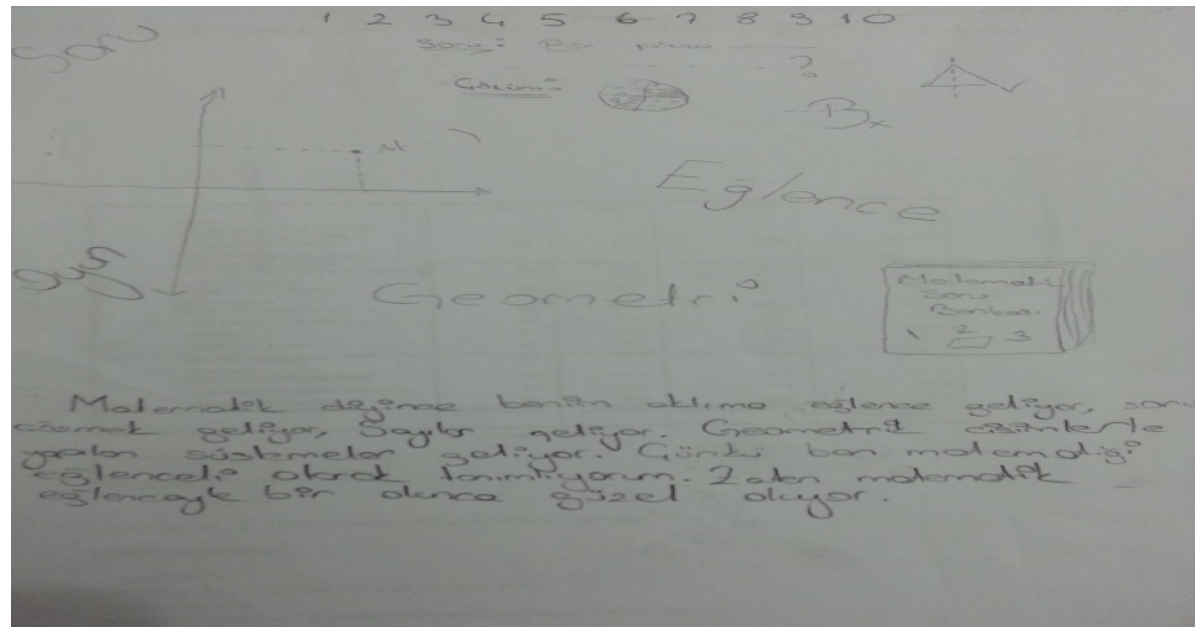

Drawing 9 


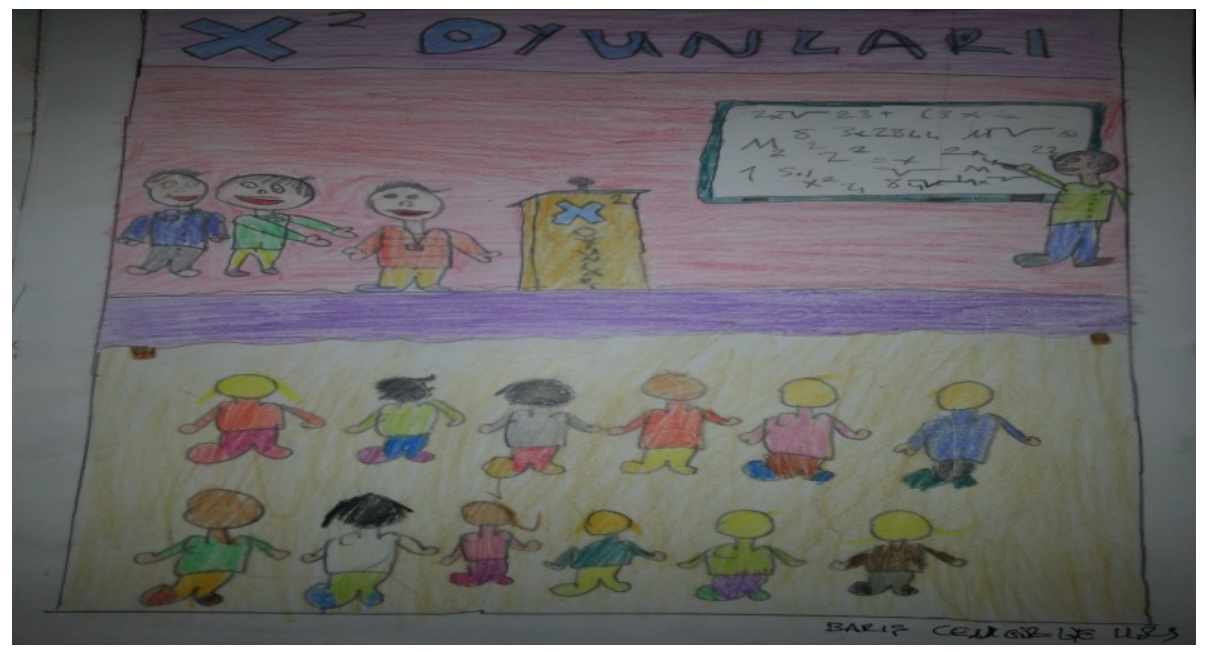

Drawing 10

When the drawings and the explanations written on the drawings by the students in the category of "a basic science containing logic" were examined, it was observed that students perceived the science of mathematics as the basis of other sciences and discoveries. Some of the drawings representing this category are displayed below:

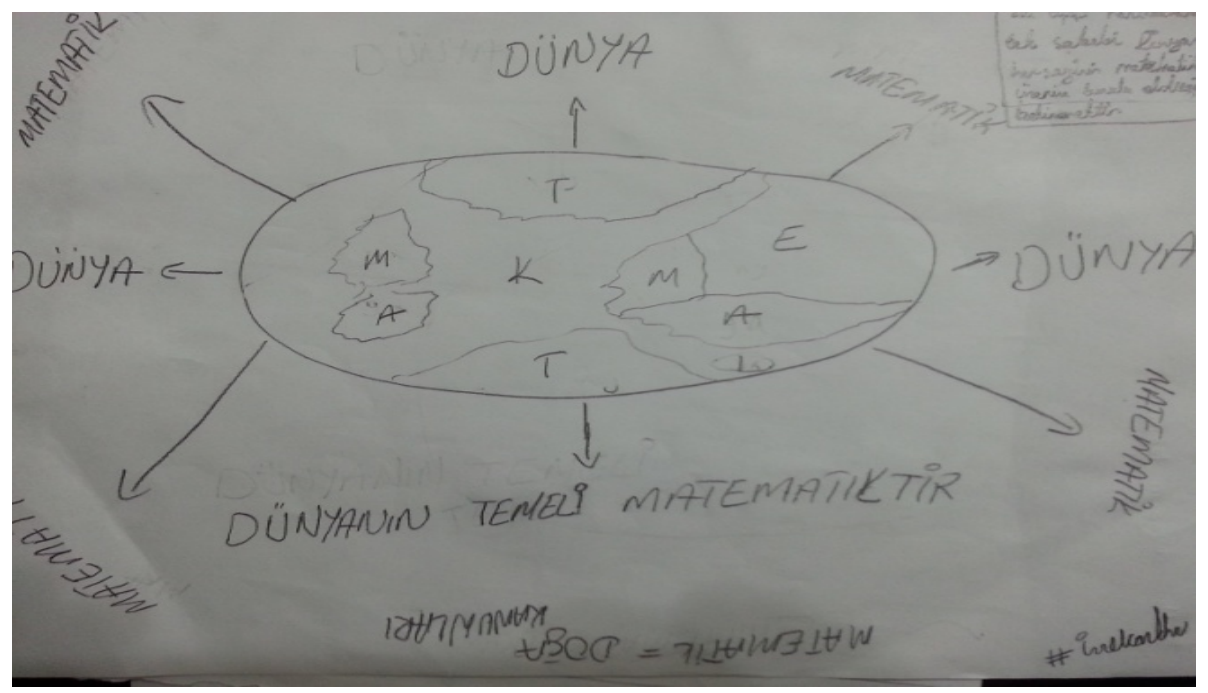

Drawing 11

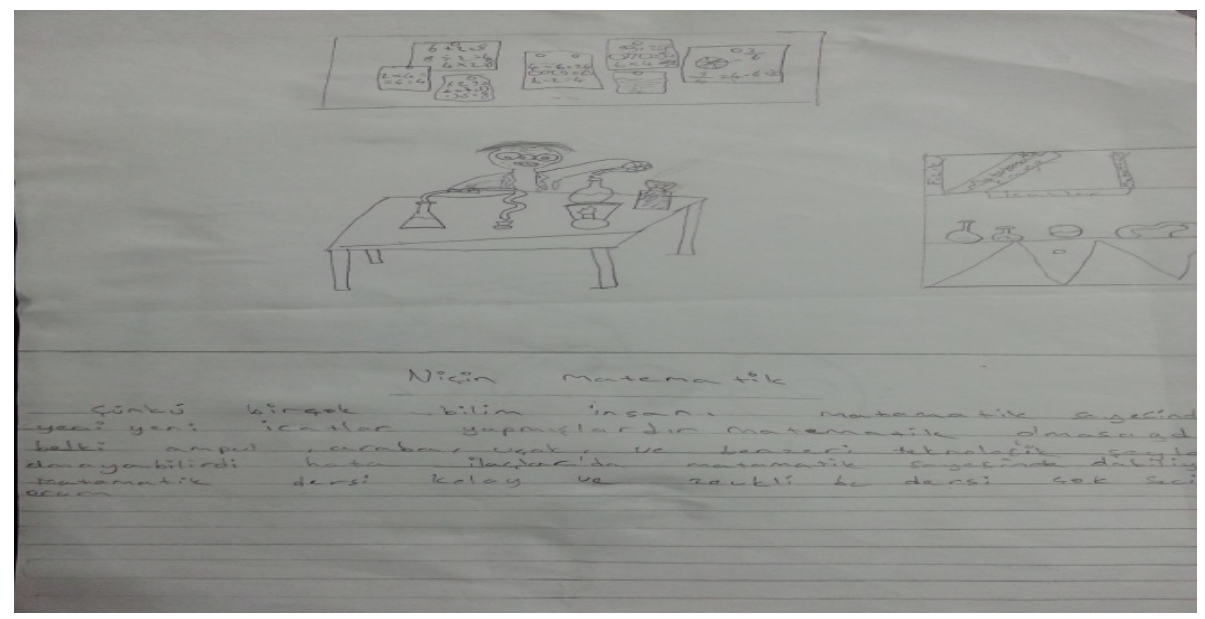

Drawing 12 
When the drawings and the explanations written on the drawings by the students in the category of "difficult and confusing" were examined, it was observed that students had difficulties in mathematics course. Some of the drawings representing this category are displayed below:

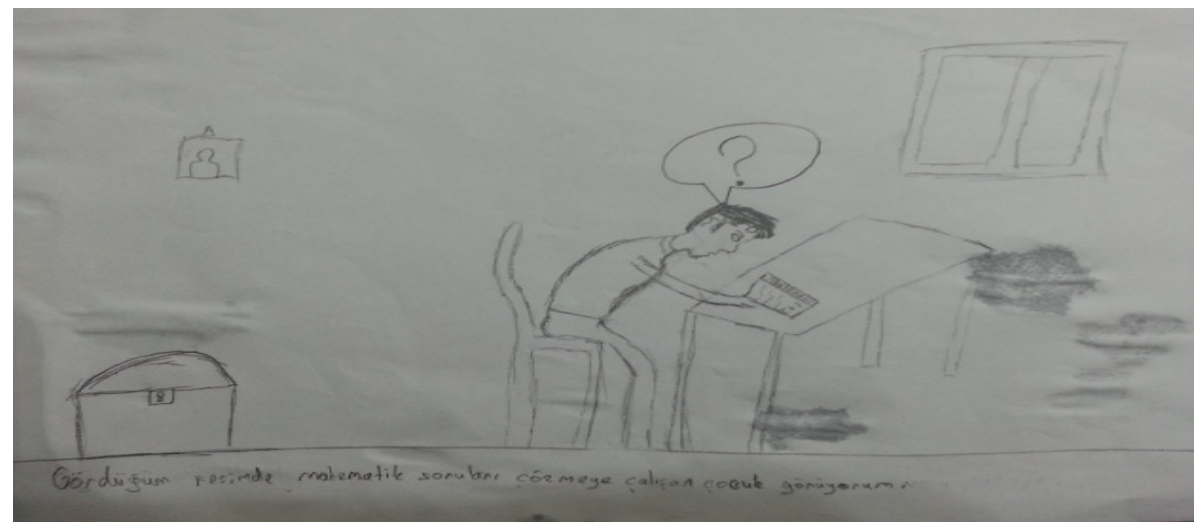

Drawing 13

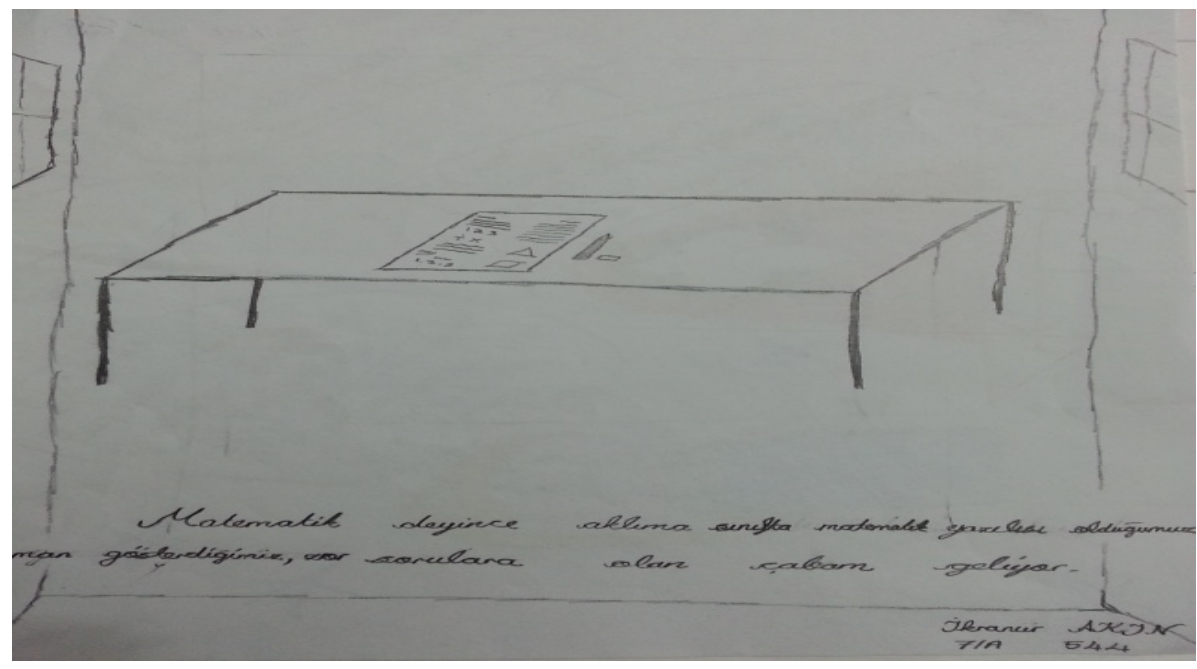

Drawing 14

When the drawings and the explanations written on the drawings by the students in the category of "formed by figures and patterns" were examined, it was observed that students perceived mathematics as geometrical figures more than numerical calculations. Some of the drawings representing this category are displayed below:

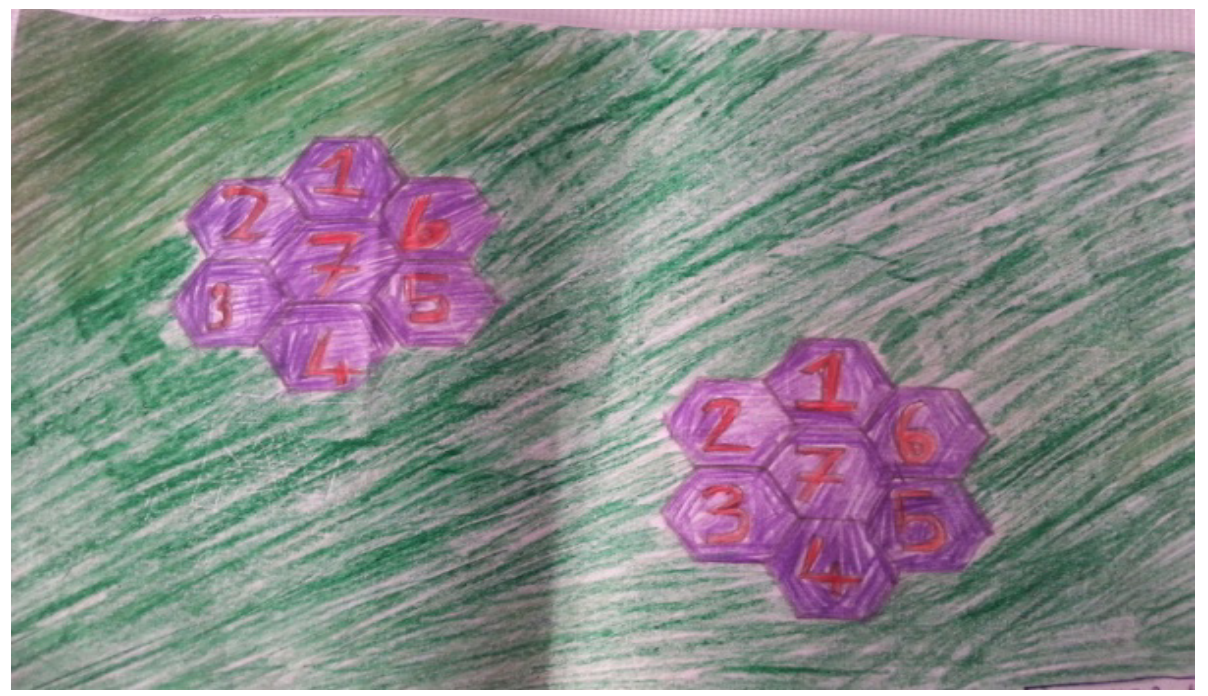

Drawing 15 


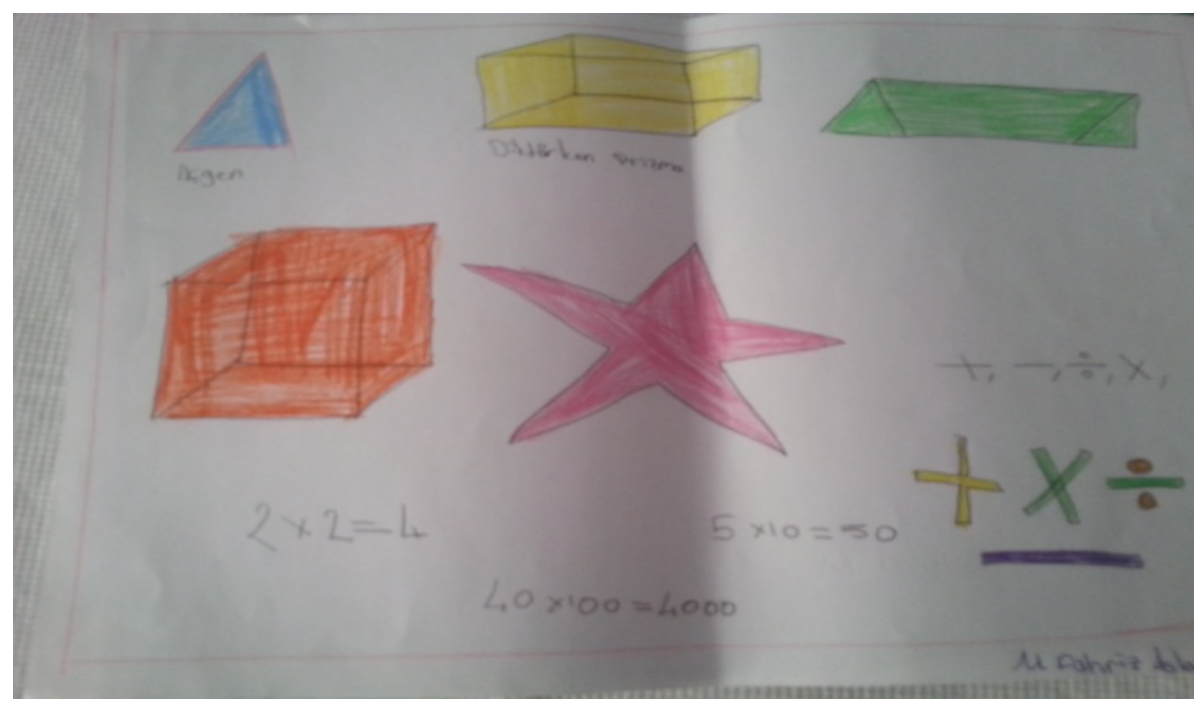

Drawing 16

When the drawings and the explanations written on the drawings by the students in the category of "learned with effort" were examined, it was observed that students thought that even those who did not like or had trouble in the course of mathematics could succeed in mathematics with the adequate effort. Some of the drawings representing this category are displayed below:

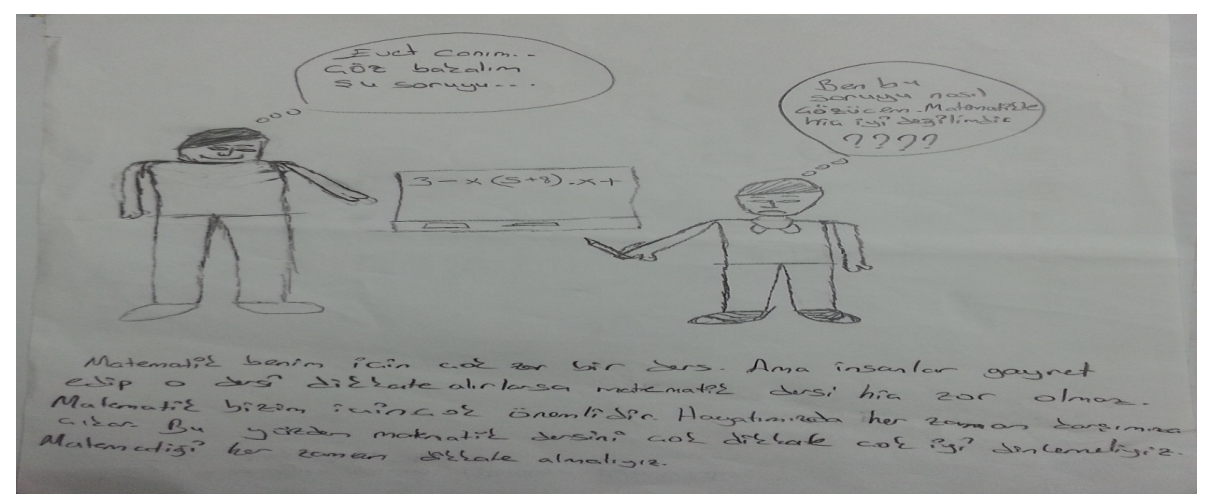

Drawing 17

\section{Discussion, Result and Suggestions}

The most prevalent categories in students' drawings were "functionality" (21.8\%), "formed by infinity and numbers" $(18.5 \%)$ and "improving mental activity" (12.8\%).

Examination of Table 1 demonstrates that the categories observed in students' drawings had mostly positive characteristics (functionality, numbers, figures, improving mental activity, fun, a logical science, could be learned by effort). The percentage for the negative category, "difficult and confusing" (7.6\%) was lower than the other categories.

When the drawings in the category of "functional in life" were examined, it was observed that students mostly drew pictures with the theme of shopping. The reason for that could be the fact that teachers stressed the theme of shopping in motivating the students in mathematics courses and created problems featuring shopping cases in the class. It could be suggested that mathematics teachers could differentiate the cases of the implementation of mathematics in real life when motivating the students.
When the drawings in the category of "required for job acquisition" were examined, it was observed that students perceived mathematics as a tool to get higher scores in the examinations and to have the desired profession at the end, instead of a discipline that they would use in their occupational development or in their future occupations. The examples in Drawing 7, where the girl telling her mother "if you had solved a lot of mathematics tests, you would not end up as a housewife" and in Drawing 8, a figure wearing a doctor's uniform using the phrase "I studied well in mathematics and I became a doctor" could be considered as the proofs of the above statement. It could be suggested that mathematics teachers should emphasize the uses of mathematics in the students' future occupations.

When the drawings in the category of "a basic science containing logic" were examined, it was observed that students perceived mathematics as above all other sciences and providing a base for all others and containing logic more than any other. It could be suggested that mathematics 
teachers could establish that logic exists in verbal courses as well as the numerical subjects.

When the drawings in the category of "difficult and confusing" were examined, it was observed that students stated that they did not like mathematics course that much and the classes were boring. In Drawing 13, the student is confused and needs help while studying and thinks "I wish my teacher was around, I would have asked him" and in Drawing 14, the student leaves the mathematics question on the desk while thinking "I think of difficult questions asked in the exams and my efforts trying to solve them when I think of mathematics" could be considered as supporting the case above. It could be suggested that mathematics educators could pay attention to the development of a positive attitude by the students towards the course and instruct the students starting from simpler subjects.

When the drawings in the category of "formed by figures and patterns" were examined, it was observed that the perception of students concerning mathematics was more about geometrical figures rather than numerical calculations. Students representing the objects around them using geometrical forms and ornamenting the walls with geometrical patterns in Drawings 15-16 support that premise. This situation could be an indication that the perception depicted in the study by İnan (2014) that "The levels of distinguishing the mathematical elements in a text of preschool pre-service teachers differ between $3 \%$ and $61 \%$. It was observed that the elements that do not contain numbers could not be distinguished well. This situation could be considered as a reflection of the perception of "limiting mathematics with numbers" in the society" is changing and should be considered as a positive development. It could be suggested that mathematics teachers should have an attitude to support their students to use tables, figures and diagrams while solving mathematical problems.

When the drawings in the category of "learned with effort" were examined, it was observed that the students thought that even the students who had troubles in and did not enjoy mathematics course could succeed in mathematics by spending sufficient effort. The thoughts of the student depicted in Drawing 17; "mathematics is a very difficult subject for me but if people try and consider that subject, it could not be difficult at all, mathematics is very important for us. It comes about in every corner of our lives" support this case. It could be suggested that teachers could help students to apprehend the subjects using increased number of activities. Because education is a process that necessitates patience, but its fruits are rather sweet.

As a result, the emphasis that the perception of mathematics reflected in student drawings was a positive one and the interest and experience of teachers are the keystones of this perception was a common theme reflected in all drawings by the students, who participated in this study.

"Your perceptions of me is a reflection of you; my reaction to you an awareness of me" To evaluate the perception of the images reflected in mathematics for students and teachers as already described above is very important. These evaluations will be useful when you are endearing mathematics to students.

\section{REFERENCES}

[1] Akerlind, G.S (2012). Variation and Commonality in Phenomenographic Research Methods. Higher Education Research \& Development, 31:1, 115-127, DOI: 10.1080/ 07294360. 2011.642845

[2] Belet, Ş.D. ve Türkan, B. (2007). Illköğretim öğrencilerinin yazılı anlatım ve resimsel ifadelerinde algl ve gözlemelerini ifade biçimleri (Avrupa birliği örneği). VI. Ulusal Sinıf Öğretmenliği Eğitimi Sempozyumu Bildiriler Kitabı (27-29 Nisan 2007). http://home.anadolu.edu.tr/ sdbelet/yayinlar/usos\%20bildiri. pdf adresinden 14.01.2015 tarihinde ulaşılmıştır.

[3] Ersoy, A. ve Türkkan, B. (2009). İlköğretim Öğrencilerinin Resimlerinde İnternet Algısı. İlköğretim Online Dergisi, 8(1), 57-73.

[4] Johnson,S.R.,Gloye,E.E. (1958) . A Critical Analysis of Psychological Treatment of Children's Drawings and Paintings. The Journal of Aesthetics and Art Criticism.17.2.242-250

[5] İnan, C. (2014). Okul Öncesi Öğretmen Adaylarının Matematik Dersini Öğretebilme Konusunda Hazır Bulunuşluk Düzeylerinin Değerlendirilmesi ( Diyarbakır İl Örnegi) Turkish Studies - International Periodical For The Languages, Literature and History of Turkish or Turkic Volume 9/8 Summer 2014, p. 537-550, ANKARA-TURKEY

[6] Kearney, S. K., \& Hyle, E. A. (2004). Drawing Out Emotions: The Use of Participant-Produced Drawings in Qualitative İnquiry. Qualitative Research, 4 (3), 361-382.

[7] Kesicioğlu,O.S., Deniz,U. (2012). Investigation Of Pre-School Children's Perception Of Teacher İn Their Drawings. Creative Education,5, 606-613

[8] Taşdemir, C. (2009). İlköğretim İkinci Kademe Öğrencilerinin Matematik Dersine Karşı Tutumları: Bitlis İli Örneği. Dicle Üniversitesi Ziya Gökalp Eğitim Fakültesi Dergisi, 12 (2009), 89-96

[9] Ünlü, E. (2007). İlköğretim Okullarındaki Üçüncü, Dördüncü, Beşinci Sınıf Öğrencilerinin Matematik Dersine Yönelik Tutum ve İlgilerinin Belirlenmesi. Dumlupınar Üniversitesi Sosyal Bilimler Dergisi, 19

[10] Yenilmez, K. (2007). İlköğretim Öğrencilerinin Matematik Dersine Yönelik Tutumları. Ondokuz Mayıs Üniversitesi Eğitim Fakültesi Dergisi, 23, (2007) 51-59

[11] Yılmaz, M. (2006). İlköğretim Altıncı Sınıf Öğrencilerinin Matematik Dersine İliş̧in Tutumlarının Bazı Değişkenlere Göre İncelenmesi. Milli Eğitim Dergisi,172

[12] Zan, R. Martiono, P.D. (2007).Attıtude Toward Mathematıcs: Overcoming The Positive/Negative Dichotomy. The Montana Mathematics Enthusiast, ISSN 1551-3440, Monograph 3,157-168 